\section{Changing science for the time}

\section{Adrian Desmond}

Georges Cuvier: Vocation, Science and

Authority in Post-Revolutionary France. By Dorinda Outram.

Manchester University Press: 1984. Pp. 299. £25, \$32.50.

Lamarck.

By L.J. Jordanova.

Oxford University Press: 1984. Pp. 118.

Hbk £7.95; pbk £1.95.

CUVIER'S aggrandisements have become a historiographic byword. The creator of stratigraphic palaeontology was also Napoleon's Inspector-General of Studies, Councillor of State from 1816 until his death in 1832, and Grand-Master of the Protestant Faculties. Darwinian propagandists derided him as a bureaucrat and bibliolater. Cuvier might have founded what Camille Limoges calls the "Macedonian Empire" of comparative anatomy, but he is still ritually censured in popular histories for leading the state opposition to Lamarck.

Dorinda Outram's Georges Cuvier, a deeply-reasoned attack on such rubberstamp historiography, is a towering achievement in the "naturalization" of science history. Provocative, occasionally

\section{IMAGE UNAVAILABLE FOR COPYRIGHT REASONS}

Georges Cuvier (1769-1832): play-off between science and political expediency.

conjectural, it is always absorbing. Outram has colonized terrain between cognitive sociology and psychology, dissecting the complex relationship between the individual, state and science that was forged during the French Revolution. This is not a study of Cuvier's comparative anatomy, but of his public persona as a savant - not the textbook history of transcendent genius, but a living biography of a man forming alliances and entering into "micropolitical" negotiations to advance his career.

The ossified image of Cuvier is that of the stern "legislator of science", arrogant, unyielding and conservative. Here he emerges as a cosmopolitan liberal, scarcely religious, a friend of erstwhile Jacobins (who attended his wedding) and champion of working-class education - aspects at odds with the prevailing caricature. In a scintillating discussion of Cuvier's "catastrophist" Discours (1812), Outram asserts that - far from Scriptural kow-towing Cuvier's abandonment of theological dogma led him to de-emphasize "causes" and endorse a historical descriptive approach. He demanded the "epistemological autonomy" of geology, staked its claim to the "new worlds of time" and, in an effort to conquer Lamarck's rival empire of conchology, founded the speciality of palaeontology, modelled after the new historical criticism. Outram's method is beguiling, and her imperial metaphors capture an expansionist era. This is a history of campaigns against competitors and annexations of nature: Cuvier's hostility towards Lamarck is a "territorial conflict" for control of the invertebrates. Patronage, property and power are the rewards for a successful playoff between social contingencies and natural resources.

For Outram, science is a "cultural commodity"; careers do not happen, they are made - hence her approach to Cuvier's rise, both in the Muséum d'Histoire Naturelle and Conseil d'Etat. She constantly questions the "heroic" view of affairs and shows that "disinterested" science is itself a myth of the scientific élite: a self-validating argument that requires a constant sanitization of history. That myth was even more essential in Cuvier's day. Given the uncertainties after the Terror (1793-1794), proclaiming a neutral ground could gain a savant immunity: "Whoever controlled the public exposition of such myths" of a politically-untainted science, she says, "was in a position to gain great public authority"'. The struggle to control the language of science climaxed during the 1830 Revolution, when Geoffroy challenged Cuvier's asocial ethos and used "popularist rhetoric" to drum up radical support for his romantic morphology based on unity of plan.

With patronage networks ramifying through the political, banking and scientific worlds, one can see why Cuvier was forced to tailor his scientific claims to political expediences; society was volatile and his power-base unstable. $\mathrm{He}$ had to renegotiate claims with successive masters during the Revolution, Empire and Restoration, which entailed subtle modifications of his scientific stance. Outram reveals how, in turn, he met the challenge of revolutionary democratization, capitalized on the colonial predations of the revolutionary army, combatted Napoleonic "egoism", and retained power during the reaction, in part by modifying the rhetoric and content of his geology and zoology. In short, she has made splendid play of the mediating structures between the public language of science and contemporary political events. Science, for all the propaganda, did not (indeed does not) inhabit a world of supralunary purity.

In Lamarck, L.J. Jordanova presents a corroborative view. Lamarck's debt to the anti-authoritarian idéologues, disliked by Napoleon, counted against him during the Empire, when the re-establishment of order became imperative. Jordanova has brought together the latest research on Lamarck, shaping it into the Oxford Past Masters format. She depicts the late

\section{IMAGE UNAVAILABLE FOR COPYRIGHT REASONS}

Jean Baptiste Lamarck (1744-1829): legacy was not transformism, but taxonomy.

Enlightenment idéologues promoting a rational science of man and redirecting naturalists to the influence of environment. Lamarck's environmentalism, classificatory precision and attitude to transformed man are evidence of this debt.

But the enigma remains: Jordanova's Lamarck comes across as a minor nobleman in favour of the Revolution, a Heraclitean figure capable of majestic biological visions, who remained at heart a sea-shell systematist. His legacy to the following generation was not transformism, but taxonomy: even English evangelicals, who execrated his ungodly flights, paid homage to his conchological classification.

Lamarck is an admirable primer, and Jordanova's strength comes from her emphasis on the continuity between Lamarck's transformism and earlier theories of life and classification. Lamarck the ancien régime rationalist, oldfashioned chemist and obsessive meteorologist became Lamarck the transformist shortly after the Terror. He died a blind pauper in 1829 , and was interred by Cuvier with a derogatory éloge. Cuvierian officialdom could certainly be heavy handed. But now Outram has taken us behind the politicking which made it so essential in a turbulent age.

Adrian Desmond is an Honorary Research Fellow in the Department of Zoology and Comparative Anatomy, University College London, and author of Archetypes and Ancestors: Palaeontology in Victorian London 1850-1875 (Blond \& Briggs, 1982/University of Chicago Press, 1984). 